Mulyasari, G., Irham, Waluyati, L. R., \& Suryantini, A. (2019). The importance of

combining various methods in assessing poverty level: The case of marine

capture fishermen in Bengkulu Province, Indonesia. Journal of International Studies,

12(2), 241-257. doi:10.14254/2071-8330.2019/12-2/15

\title{
The importance of combining various methods in assessing poverty level: \\ The case of marine capture fishermen in Bengkulu Province, Indonesia
}

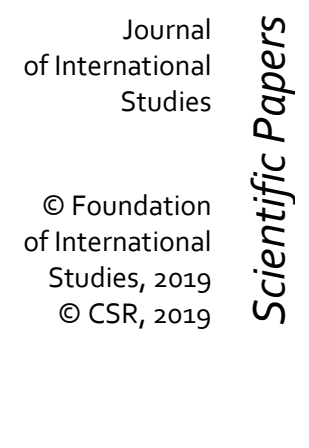

\author{
Gita Mulyasari \\ Department of Agricultural Socio-Economics, Faculty of Agriculture, \\ Universitas Bengkulu, \\ Indonesia \\ gita.mulyasari@unib.ac.id
}

Irham

Faculty of Agriculture, Universitas Gadjab Mada (UGM), Indonesia

Lestari Rahayu Waluyati

Faculty of Agriculture,

Universitas Gadjah Mada (UGM), Indonesia

\author{
Any Suryantini \\ Faculty of Agriculture, \\ Universitas Gadjah Mada (UGM), \\ Indonesia
}

Abstract. The measurement of poverty can be analyzed by various methods and each method has its own advantages and disadvantages. The single dimensional model has a weakness since it only measures poverty in its monetary aspect, as income, while multidimensional method measures poverty by considering various dimensions but excluding the income aspect. Furthermore, it is important to combine both models so that the measurement of poverty could be more comprehensive. The study describes the method of poverty measurement by using: 1) single dimension poverty measurement, promoted by the Asian Development Bank (ADB), the World Bank, Food and Agriculture Organization (FAO); 2) Multidimensional poverty measurement, promoted by the Central Bureau of Statistics (BPS), and Multidimensional Poverty Index (MPI) by Alkire and Foster. The study was conducted in Bengkulu Province, Indonesia, and the data was collected by means of interviewing 90 marine 
capture fishermen, randomly selected. The results of this study show that each poverty measurement gives a difference in the poverty level of fishermen because it is not able to describe the actual condition of fishermen's poverty. By combining both models, it is found that fishermen's poverty is affected by ship weight, fishing distance, and household size.

Keywords: poverty line, multidimensional poverty, marine capture fishermen.

JEL Classification: A13, C40, D63, Q22

\section{INTRODUCTION}

"The concepts of poverty have developed rapidly over the last thirty years, and international attention is now focused more sharply on poverty reduction than it was twenty years ago" (Agola \& Awange, 2014). Poverty is a big challenge all around the world, especially, in non-developed and developing countries. Poverty is not just about money and it is not easy to define because poverty affects different people in different ways. For example, in many communities, it is about access to basic needs such as food, healthcare, and education (Rahimi, 2015). Poverty reduction becomes a top priority on the policy agenda of the Government of Indonesia. Various policies to overcome the problem of poverty have been carried out, including stability in food prices, village subsidy and funds programs, and social assistance. In Indonesia, since 2000 to 2013, there were certain years when economic increase was not followed by a decrease in the poverty rate and also several years which showed a decline in economic development but poverty also decreased. This may be because the poverty analysis tool used in Indonesia is unable to explain poverty in a comprehensive manner.

Understanding poverty now has experienced expansion and poverty is no longer seen only in its economic aspect but also in its social, cultural, political, education, and health aspects. It is estimated that there is something wrong in formulation and implementation of policies aimed to eradicate poverty and empower the poor. During this period, poverty is more often associated with the economic dimension because it most easily observed, measured, and compared, whereas poverty is also related to various other dimensions including social, cultural, sociopolitical, environmental (natural and geographical) ones as well as healthcare, education, religion, and even manners. Analyzing poverty in a multidimensional manner is necessary for better formulation of poverty alleviation policies.

The issue of community poverty is not just a form of income incapacity but it has expanded to a form of social and political powerlessness (Suryawati, 2005). When there are some people who cannot access basic education or basic healthcare services due to economic inability, it can be said that the people are poor. Likewise, households who own houses with bare earth floor, lack of good sanitation, lack of energy for lighting and cooking, are also considered as a part of poverty. Poverty is also considered as a form of development problems caused by the negative impact of unbalanced economic growth so that income disparities between communities and inter-regional income gap widens (Harahap, 2006).

A pluralist conception of poverty recognizes that deprivations are multi-faceted and not limited to only income considerations. Narayan \& Petesch (2007) cogently argue that "lack of money is just one of many disadvantages of being poor and one of the many obstacles to escaping a life of impoverishment". The concern that monetary measures do not permit a nuanced, yet complex understanding of poverty experiences was the key motivation behind the UNDP Multidimensional Poverty Index (MPI) introduced in the 2010 Human Development Report (Alkire \& Santos, 2010). The UNDP-MPI evaluates poverty based on households' deprivation in three basic dimensions - education, healthcare, and living standards. Various indicators are used to measure each of these dimensions, and they represent a mix of 
commodities and actual functioning. While multidimensional measure takes cognizance of the interconnectedness of deprivations, one of the shortcomings is the use of household as the unit for analysis. That is, the UNDP-MPI is derived from household level averages rather than personal information. This is mainly due to data constraints as individual-level information is not routinely collected for all dimensions included in the poverty measure (for example, healthcare and nutrition data are typically available only for certain age and sex categories in the Demographic and Health Surveys on which the UNDP-MPI is based). Operationalization of the multidimensional measures has become feasible due to availability of detailed household-level surveys. But paucity of individual-level data in these surveys has been limiting. Although poverty is an individual experience, all poverty measures typically use the household as the unit of analysis whereas per capita values of household members are derived from household aggregates. There is no way to evaluate inequalities or differences in poverty experience within households.

Bengkulu Province is one of the coastal areas located on the west coast of Sumatra and benefiting from marine products and fisheries. According to the data on capture fishery production until 2018, the territorial sea of Bengkulu province (0-200 mil) contains 126,217 ton/year fish potential with its utilization rate being $85.30 \%$, so there is still about $14.70 \%$, or 75,345 ton that could be potentially utilized by fishermen in Bengkulu province. If we look at the potential of these fish resources, the fishermen community should be able to improve their welfare by exploiting the existing coastal opportunities. However, the actual condition is the opposite, the communities remain poor, as seen from the fishermen's welfare level in Bengkulu which is relatively lower as compared to the employment outside the fishing sector. The Central Bureau of Statistics (BPS) of Bengkulu Province recorded the number of poor people in this province, as of March 2016, reaching 328.61 thousand people (or 17.32\%), and the fishermen still dominate among the poor in Bengkulu. The present study is based on the survey conducted among marine capture fishermen throughout Bengkulu Province, Indonesia, in 2018. The current study explores the disparities in various dimensions of deprivation among the fishermen so that to develop better antipoverty strategies.

\section{FISHERMAN AND POVERTY}

Fishermen are one of those identified as poor. Various studies on the lives of fishermen generally emphasize poverty and economic uncertainty, due to the difficulties of life faced by fishermen and their families (Acheson, 1981; Emmerson, 1980). The fishermen can be said not only insufficient, but also still underdeveloped, including in terms of education. The social limitations experienced by fishermen have not been realized in the form of alienation, because physically fishing communities cannot be said to be isolated or isolated. However, it is more manifested in their inability to take part in market economic activities profitably, which is indicated by their weakness in developing organizations outside the environment of their relatives or local communities (Boedhisantoso, 1999).

Poverty is a structural and multidimensional problem, which includes politics, social, economic, assets and others. The dimensions of poverty also appear in various forms, such as (a) not having an organization that is able to fight for the aspirations and needs of the poor, so that they are completely excluded from the important decision-making processes that concern themselves. As a result, the poor do not have adequate access to the various key resources needed to properly carry out their lives, including access to information. (b) the integration of the poor into existing social institutions, so that they are excluded from the dynamics of society; (c) low income so that they are unable to meet their living needs to a reasonable extent and (d) low ownership of the poor to various things that can become their living 
capital, including assets of human capital, work equipment, capital of funds, housing, settlements and so on (Setiadi, 2006)

In Indonesia, poverty in fishing communities can be characterized by the fluctuating income, consumptive expenditure, low family education level, existing institutions do not support the occurrence of equal income, the potential of family labor (wife and child) cannot be utilized properly, and access to capital the low (Hermanto, 1995). In addition, the conditions of poverty and socio-economic disparities in the lives of fishing communities are also characterized by inadequate quality of settlements. Poor fishing villages will be easily identified from the condition of their residential houses. Very simple houses, woven with bamboo walls, sandy dirt floors, thatched roofs, and limited ownership of household furniture are the dwellings of labor fishermen or traditional fishermen. The lives of poor fishermen can also be seen from their children's education level, daily consumption patterns and income level. Because the income level of fishermen is low, it is logical that the education level of their children is also low. Many fisherman children were dropped out before graduating from elementary school or even if they graduate, they could not continue their education to junior high school. In addition, the most basic living necessity for poor fishermen households is fulfilling food needs. Other basic needs, such as the feasibility of housing and clothing are used as secondary needs. The need for food is the main prerequisite for fishermen households to survive (Kusnadi, 2002). The conditions experienced by fishermen are certainly very worrying, because fishermen are the spearhead of fisheries management in Indonesia. Given that the rate of population growth continues to increase, then fishermen required to fulfill the fisheries product needed by the increasing population.

With all the limitations, fishermen must survive and find solutions to the problems of poverty they faced. The adaptation strategy that is usually done is to mobilize family members to look for additional income outside the fisheries sector (Table 1). Women are usually fully involved in the activities of socioeconomic institutions that have been formed, such as social gathering, recitation activities with dimensions of economic interests, savings and loans, and social networks that they can use to support family survival. The presence of these institutions is a strategy for adaptation of fishing communities in facing the difficulties. In addition, fishermen are also looking for additional income when fishermen cannot go to sea. But only a small number of fishermen have side jobs to earn extra income (Fig. 1).

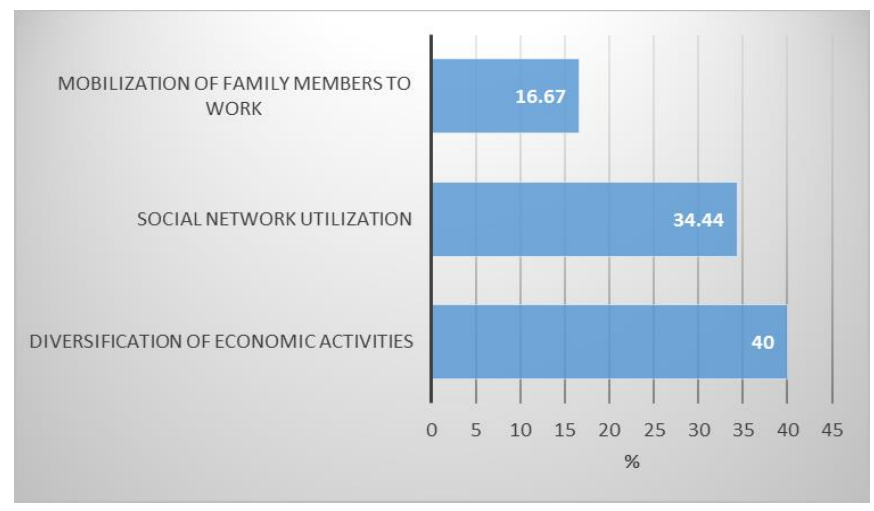

Figure 1. Solving of fishermen poverty

Fishermen remain in the fisheries sector because of their low opportunity costs, so that other alternative economic activities that can be obtained besides fishing are very limited. If the opportunity cost is low, fishermen tend to continue to carry out their business even though the business is no longer profitable and efficient (Subade \& Abdullah, 1993). Fishermen remain in poverty because of their desire to live life (preference for a particular way of life). Fishermen prefer to have the satisfaction of life that can be obtained from fishing and not as actors who are oriented towards increasing income. Because of the way of life, 
whatever happens to the situation is not considered a problem. The way of life is very difficult to change. Therefore, although other people viewed that the fishermen live in poverty, for fishermen themselves, it is not poverty and fishermen may feel happy with that life (Panayotou, 1982; Subade \& Abdullah, 1993).

In Indonesia, determination of poverty lines is of two kinds, namely absolute poverty and relative poverty. Absolute poverty is defined as a situation where the level of absolute income from a person is insufficient to meet basic needs, such as food, clothing, housing, health and education. The real consumption is stated quantitatively and or in money based on the price in the base year (Prayitno \& Aryad, 1987). On the other hand, relative poverty is the share of national income received by each income group. In other words, relative poverty is very closely related to the problem of income distribution (Kuncoro, 2006). In Indonesia, the measurement of poverty has been based on income or consumption such as the National Poverty Line calculated by the Central Bureau of Statistics using the basic need approach, then the Asian Development Bank, World Bank, and the Food and Agriculture Organization. Measuring poverty from the consumption approach using the basic need approach carried out by the government is one form of narrowing down the issue of poverty, especially fisherman poverty in Indonesia. Poverty not only involves nominal monetary calculations where the poverty line is calculated as a standard like the national poverty line, but poverty is a multidimensional aspect.

\section{METHODOLOGY}

\subsection{Study Area}

This research was conducted in Bengkulu Province, which is the seventh poorest province in Indonesia and the highest percentage of poverty on the Sumatra island. Data were collected from coastal areas of Bengkulu Province, including Bengkulu City, North Bengkulu Regency, and South Bengkulu Regency. Sites selection were done by using a purposive technique based on a number of fishermen population (more than 200 people) and the existence of fish auction. The coastal area of Bengkulu Province located on the west coast of Sumatera Island with a coastline of more than $525 \mathrm{~km}$. This coastal area lies parallel to the Bukit Barisan Mountain and facing the Indonesian Ocean. Bengkulu City has an area of $151.70 \mathrm{~km}^{2}$, while North Bengkulu Regency has $4424.60 \mathrm{~km}^{2}$ with a coastline of about $262.63 \mathrm{~km}$. North Bengkulu coastal area has high potential of natural resources both of biological and non-biological that support regional economic growth. South Bengkulu Regency is also directly facing the Indonesian Ocean with a coastline of more than $60 \mathrm{~km}$ long (BPS, 2017) (Fig. 2).

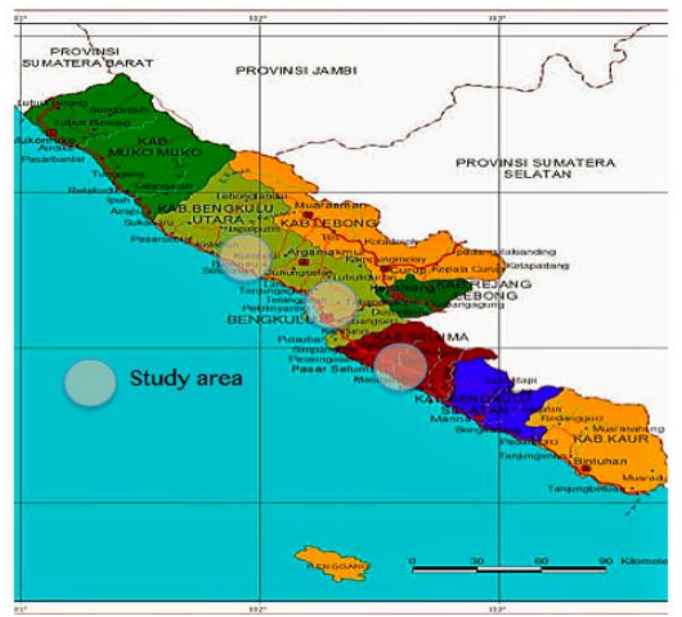

Figure 2. The Study Areas 


\subsection{Sampling, Questionnaire, and Data Collection}

In this study, the unit of analysis was the household and the head of marine capture fishermen as the key informant. The method used in determining the respondents is by simple random sampling with a total of 90 fishermen were selected. Data were collected using face-to-face interviews between March and June 2018. The questionnaire (https://drive.google.com/drive/my-drive) was carefully designed to get information of poverty. The first part of the questionnaire was about information on fishermen's socioeconomic characteristics consisting of age, education, experience, household size, income, and capture fisheries activities. Next is to explore the information needed to measure fisherman poverty such as income, health dimensions, education dimensions, quality of life dimensions, and various poverty indicators used in this study. The collected data consists of primary data and secondary data.

\subsection{Data Analysis}

This study measures poverty by using two approaches, namely single dimensional poverty approach and multidimensional poverty approach (Fig. 3). The single dimensional is mostly done in Indonesia to measure poverty by calculating per capita income or consumption expenditure. But at this time there is a shift in poverty measurement, where a single dimension poverty approach is considered unable to describe poverty comprehensively, because of a simple calculation indicator. Even though poverty is a multidimensional phenomenon that is not only related to economic aspects but related to other aspects. So that the measurement of poverty is expected to be more comprehensive if approached with multidimensional poverty approach.

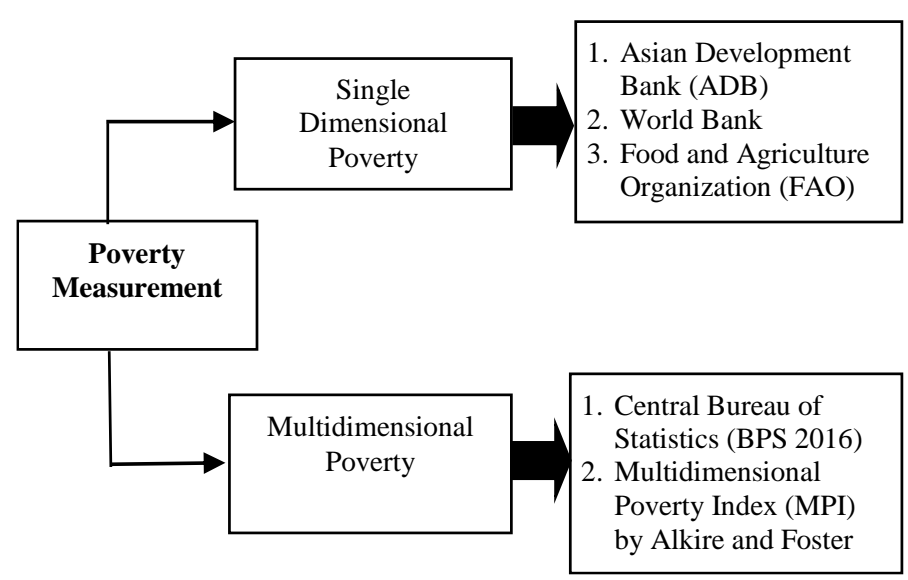

Figure 3. Poverty Measurement

\subsubsection{Single Dimensional Poverty}

Single dimensional poverty promoted, 1) the Asian Development Bank sets a poverty line in Indonesia with a value of US $\$ 1.25 /$ capita/day; 2) the World Bank with a value of US $\$ 2 /$ capita/day; 3) Food and Agriculture Organization (FAO) criteria for households classified as non-poor if capita income per year is more than US $\$ 1,500$ for developing countries including Indonesia. 


\subsubsection{Multidimensional Poverty}

Multidimensional Poverty promoted the Central Bureau of Statistics (BPS) and Multidimensional Poverty Index (MPI) by Alkire and Foster. There are 14 criterias for poverty according to BPS standards, where marine capture household gets a minimum of nine indicators of poverty, then a household can be said to be poor. Indicators of poor according to BPS, namely: building area, floor, type a house wall, sanitation, electricity, drinking water, cooking fuel, consumption of meat/milk/chicken, purchase new clothes, eating a day, cost of healthy care, income of head of household, education, and saving.

Since 2010, UNDP and OPHI agreed on an initiation of measuring new poverty through the Multidimensional Poverty Index (MPI) which was published in HDR 2010. This study uses a Multidimensional Poverty Index (MPI) to analyze the poverty of marine capture fishermen. MPI sees a broader poverty structure, not just income or consumption but defining it multidimensionally such as education, health, and quality of life (Table 1).

$$
\begin{gathered}
M=H x A \\
H=\frac{1}{n} \sum_{i=1}^{n} q i \\
A=\frac{\frac{1}{d} \sum_{i=1}^{n} \sum_{j=1}^{d} g_{i j}}{\sum_{i=1}^{n} q_{i}}
\end{gathered}
$$

Where $\mathrm{M}$ is multidimensional

poverty index, $\mathrm{H}$ is incidence and $\mathrm{A}$ for intensity.

Description of MPI indicators

\begin{tabular}{|c|l|l|}
\hline Dimensions & \multicolumn{1}{|c|}{ Indicators } & \multicolumn{1}{c|}{ Description } \\
\hline \multirow{2}{*}{ Health } & Nutrition & $1=$ mal nutrition; $0=$ otherwise \\
\cline { 2 - 3 } & Child mortality & $1=$ child mortality; $0=$ otherwise \\
\hline \multirow{2}{*}{ Education } & Years of schooling & $1=$ if $\leq 5$ years; $0=$ otherwise \\
\cline { 2 - 3 } & School attendance & $1=$ if Child/children not attend school; $0=$ otherwise \\
\hline \multirow{4}{*}{ Living Standard } & Cooking fuel & $1=$ firewood; $0=$ otherwise \\
\cline { 2 - 3 } & Sanitation & $1=$ Public toilet (inadequate sanitation); $0=$ otherwise \\
\cline { 2 - 3 } & Water & $\begin{array}{l}1=\text { No access to clean water or } 30 \text { minutes' walk to get clean } \\
\text { water; } 0=\text { otherwise }\end{array}$ \\
\cline { 2 - 3 } & Electricity & $1=$ no electricity; $0=$ otherwise \\
\cline { 2 - 3 } & Floor & $1=$ ground floor; $0=$ otherwise \\
\cline { 2 - 3 } & Assets & $\begin{array}{l}1=\text { no assets like radio, tv, refrigerator, cellular phone, } \\
\text { motorbike, car, etc.; } 0=\text { otherwise }\end{array}$ \\
\hline
\end{tabular}

Source: Alkire \& Foster, 2011 


\subsubsection{Factors affecting poverty}

This study uses binary logistic regression analysis methods because the dependent variable is nominal data that has two categories $(1=$ poor, $0=$ Not Poor $)$. The binary logistic regression model in this study is a single dimensional model based on income and multidimensional model based on multidimensional weight from MPI.

$Y_{1}=\beta_{0}+\beta_{1} X_{1}+\beta_{2} X_{2}+\beta_{3} X_{3}+\beta_{4} X_{4}+\beta_{5} X_{5}+\beta_{6} X_{6}+\beta_{7} X_{7}+\beta_{8} X_{8}+\beta_{9} X_{9}+\beta_{10} X_{10}+\varepsilon_{i}$

(Single dimensional model)

$Y_{2}=\beta_{0}+\beta_{1} X_{1}+\beta_{2} X_{2}+\beta_{3} X_{3}+\beta_{4} X_{4}+\beta_{5} X_{5}+\beta_{6} X_{6}+\beta_{7} X_{7}+\beta_{8} X_{8}+\beta_{9} X_{9}+\beta_{10} X_{10}+\varepsilon_{i}$

(Multidimensional Model)

Where:
$\mathrm{Y}_{1}=$ Income $(\mathrm{Rp} / \mathrm{month})\left\{\begin{array}{l}1=\text { Poor } \\ 0=\text { Not Poor }\end{array}\right.$

$\mathrm{Y}_{2}=$ Multidimensional weight $\left\{\begin{array}{l}1=\text { Poor } \\ 0=\text { Not Poor }\end{array}\right.$

$\beta_{0}=$ Constant

$\beta_{1}, \beta_{2}, \ldots \ldots, \beta_{9}=$ regression coefficient

$\mathrm{X}_{1}=$ Years of schooling (years)

$\mathrm{X}_{2}=$ Age (years)

$\mathrm{X}_{3}=$ Experience (years)

$\mathrm{X}_{4}=$ Household size (person)

$\mathrm{X}_{5}=$ Catch capacity $(\mathrm{kg})$

$\mathrm{X}_{6}=$ Ship weight $(\mathrm{GT})$

$\mathrm{X}_{7}=$ Work time (hours)

$\mathrm{X}_{8}=$ Ship ownership (dummy variable)

$\mathrm{X}_{9}=$ Distance (miles)

$\mathrm{X}_{10}=$ Asset value $(\mathrm{Rp})$

\section{CHARACTERISTICS OF FISHERMEN AND MARINE CAPTURE BUSINESS}

Based on socio-economic characteristics, fishermen in the coastal area of Bengkulu are small fishermen or traditional fishermen who have an average vessel weight of 14 GT (Table 2). Small fishers in general, are the poorest group of people (the poorest of the poor) and they become fishermen in a relatively long time, also have a very high risk, both due to natural conditions and conditions of competition between fishermen, and uncertain income. This happens because being a fisherman is not just a livelihood but is the only way of life. Small fishermen do fishing using boats and simple (traditional) fishing gear. With the limitations of the boat and its fishing gear, the range of the fishing area is limited, usually only 6 nautical miles from the coastline (Retnowati, 2011). In general, small fishermen in Bengkulu Province have an average catch area of 6.44 miles with a catch capacity of 39.41 tons/trip. 
Socioeconomic characteristics of fishermen and marine capture business

\begin{tabular}{|l|c|c|c|c|}
\hline \multicolumn{1}{|c|}{ Socioeconomic Characteristics } & Min & Max & Mean & Std. Deviation \\
\hline Fishermens' age (years) & 17 & 66 & 39.12 & 9.76 \\
\hline Years of schooling (years) & 0 & 17 & 7.49 & 3.31 \\
\hline Fishermens' experience (years) & 3 & 36 & 17.44 & 7.63 \\
\hline Household size (person) & 0 & 8 & 3.24 & 1.20 \\
\hline Income from fisheries (Rp/month) & $150,000 .-$ & $7,800,000 .-$ & $2,266,607.06$ & $1,438,975.13$ \\
\hline Income from non fisheries (Rp/month) & 0 & $1,866,550 .-$ & $263,670.72$ & $441,646.92$ \\
\hline Consumption expenditures (Rp/month) & $400,00 .-$ & $4,845,000 .-$ & $1,393,083.33$ & $789,437.03$ \\
\hline Catch capacity (ton/trip) & 5 & 300 & 39.41 & 43.69 \\
\hline Ship Crew (person) & 0 & 4 & 0.72 & 1.18 \\
\hline Fishing distance (miles) & 1 & 22 & 6.44 & 5.17 \\
\hline Ship weight (GT) & 0.5 & 40 & 14.88 & 14.68 \\
\hline Fishing time (Hours) & 2 & 12 & 7.17 & 2.34 \\
\hline Fishermens' fishing trip (times/month) & 4 & 30 & 20.74 & 4.45 \\
\hline
\end{tabular}

In addition, the average income level of fishermen in Bengkulu Province is also relatively low with an average consumption expenditure of $61.46 \%$ of the income received by fishermen. Most fishermen in Bengkulu Province do not have side jobs and have a very high dependence on the capture fisheries sector, so that with relatively low income levels, fishermen find it difficult to improve their family welfare. Fishermen in Bengkulu province are still classified as fishermen in productive age with an average age of 39 years. Work as fishermen require strong physical because it deals with a natural environment that can not be predicted risks. In addition, the average level of education of fishermen is relatively low at 7 years so that fishermen find it difficult to get jobs outside the capture fisheries sector. Jobs as small fishermen rely more on muscle strength, or energy, so these fishermen put aside the level of education. Formal education cost is relatively expensive for poor fishermen, make it as obstacles for them. Structural poverty makes fishermen unable to pursue a proper and adequate formal education due to limited income. This phenomenon continues occur for generations in the family.

\section{EMPIRICAL RESULTS AND DISCUSSIONS}

The wealth of Bengkulu marine capture fishermen has not been able to be managed in a modern manner, which in the end most fishermen still live below the poverty line. This is because fishermen in Bengkulu still use minimum traditional fishing equipment. While the facilities provided to fishermen are also considered not optimal so that the catch of fishermen is still low. The fish auction places (TPI) built by the government were not in line with fishermen's expectations, because the location was far from landing traditional fishing ships. The impact also makes investors less glimpse of Bengkulu's marine wealth potential. Until now, supporting infrastructure facilities and infrastructure were inadequate such as roads and electricity. In fact, it is a vital means for fishermen to increase their catch.

Figure 4 shows that there is a difference between single dimensional and multidimensional poverty. The percentage of poverty with the criteria of the Food and Agriculture Organization (FAO) is the highest, which is $33.33 \%$ and followed by the criteria of poverty according to BPS 2014 , which is $30 \%$. The percentage of poverty will be more comprehensive if a combination of methods of measuring poverty between single dimension and multidimensional is done. One important requirement for a poverty alleviation policy to be achieved is that there must be clarity about the accurate number of poor people in Indonesia. So it is important to use the right poverty measurement method so that the criteria of who or which community groups fall into the poor category becomes accurate. 


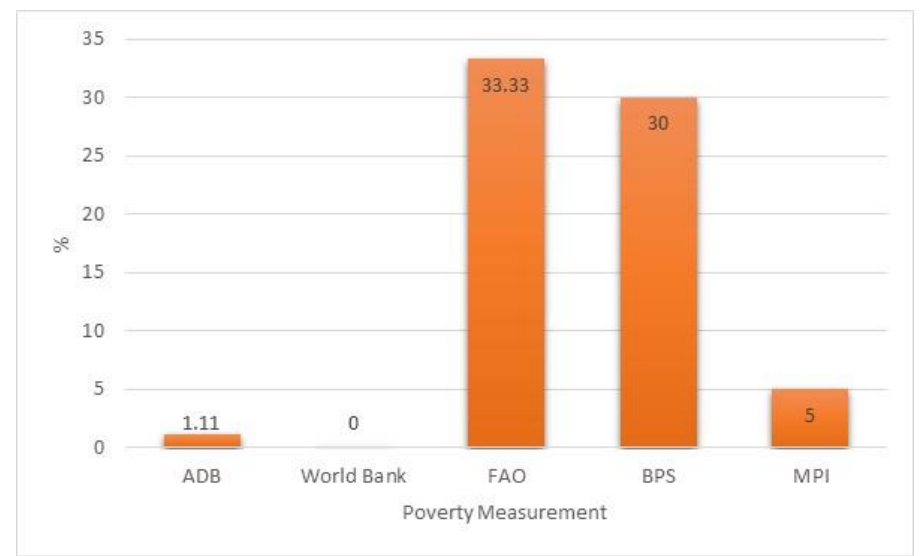

Figure 4. Results of Poverty Measurement

\subsection{Single Dimensional Poverty}

The results of the identification of poverty figures based on three categories, namely the Asian Development Bank, the World Bank, and the Food and Agriculture Organization showed far different results. The criteria of the Asian Development Bank (ADB) sets the standard of the poverty line with a value of US\$1.25/capita/day or equivalent to Rp. 17,260.00/capita/day and based on ADB criteria (Fig. 4) which is known that fishermen in Bengkulu Province 98.89 per cent are not poor, or only about 1.11 per cent of fishermen are classified as poor. Whereas according to World Bank criteria which set a poverty line standard with a value of US $\$ 2 /$ capita/day or equivalent to Rp. 27,616.00/capita/day, indicating that fishermen in Bengkulu Province as a whole are not poor fishermen (Fig. 4), which means that fishermen's income has exceeded the standard per capita income per day set by the World Bank.

The FAO sets the standard of the poverty line based on per capita income per month according to the economic category of a country. Determination of the selected poverty line is based on economic development, namely because Indonesia is a developing country, then the poverty line standard used is Rp. 20,712,000/capita/year. If fisheries fishermen can generate more income than the FAO poverty line standard, the fishermen are classified as not poor and vice versa. Based on FAO criteria it can be seen that most of the fishermen in Bengkulu Province are classified as poor by 33.33\% (Fig. 4). Rowntree (1901) cited in Viet-Wilson (1986) formulates that a family is included in primary poverty if the overall income cannot meet the minimum needs for physical/body needs (ie food consumption). Poverty is described in addition to the failure to meet food needs standards, also more generally based on the comparison of the standard poverty line, which is said to be poor if the income is lower than the poverty line.

\subsection{Multidimensional Poverty}

\subsubsection{Central Bureau of Statistics}

The Central Bureau of Statistics is an institution that functions in the establishment of a national statistical system. Poverty criteria according to BPS consist of 14 indicators which cover the area of residential buildings, type of floor, type of wall, sanitation, electricity, sources of drinking water, cooking fuel, consumption of animal protein, purchase of new clothes, number of meals in a day, medical expenses, sources income of head of household, education of head of household, and assets. Figure 4 shows that $70 \%$ of fishermen in Bengkulu are classified as non-poor, while 30 per cent are classified as poor. Fishermen are classified as poor are fishermen or ship crews (ABK) who do not own their own 
boats and are bound to patron-client relations. In addition, the increasing number of aid and policies focused on the capture fisheries sector in Bengkulu provides opportunities for fishermen to improve the economic conditions of their families. Based on poverty indicators according to BPS, it is known that the largest percentage of fishermen in Bengkulu have a wall of residence from the wall without plastering and a source of income as a fisherman who is a source of livelihood from the poor in Indonesia (Fig. 5).

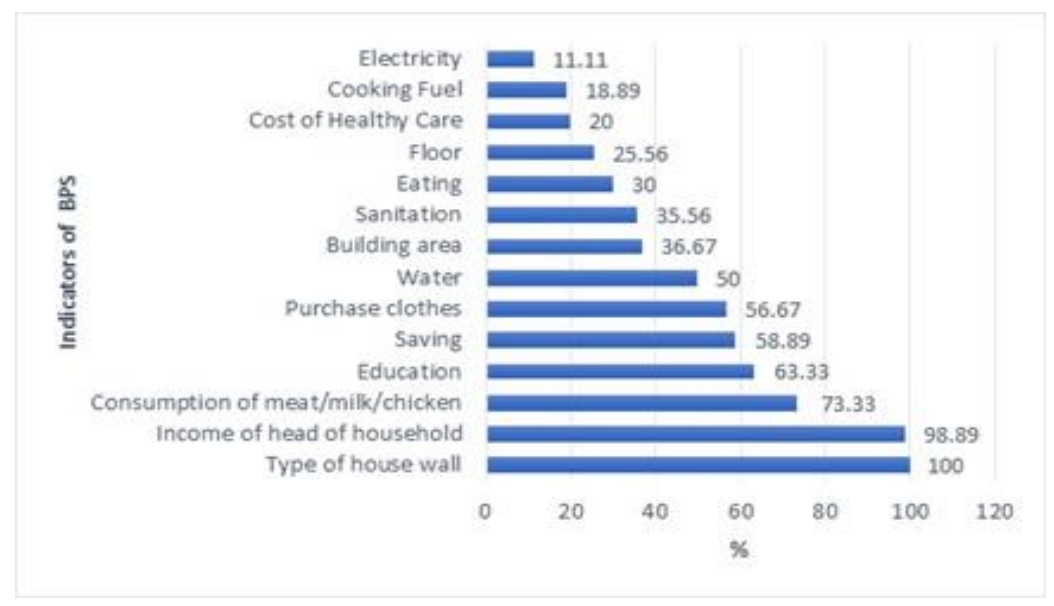

Figure 5. Percentage of Poverty based on BPS Poverty Indicator

Faturochman (1994) explained that physically the condition of poor households does not seem difficult to see which is supported by the results of an analysis of the type of house walls. Fewer poor households have houses with permanent walls. In the village, wooden houses are also owned more by poor households, whereas in the city there is no clear relationship between the economic status of households and types of wooden houses. Overall, it can be concluded that poor households mostly live in houses with non-permanent walls, while households with adequate wealth are mostly walled houses. In addition, poor households have a house with a narrower floor area and poorer floor quality than a house owned by a rich person or family. If the floor area and type of floor are compared, the type of floor gives information about the status of the household that is more prominent than the floor area.

\subsubsection{Multidimensional Poverty Index}

The MPI for a country is calculated as the product of the Headcount $(\mathrm{H})$, which is the percentage of households whose weighted deprivation lies above the 33\% cut-off and are therefore considered multidimensionally poor, and the intensity of deprivation (A). This intensity reflects the weighted sum of deprivation for only the multidimensionally poor households within each country, and thereby the average intensity of poverty for these households. By construction, those households that are not poor are not included within the intensity and therefore the intensity is always above $33 \%$ at least.For UNDP, MPI is an integrated part of the Millennium Development Goals (MDGs) framework which extends poverty indicators and sees multidimensional poverty as an initial strategy in the framework of global poverty reduction. The dimensions in MPI include dimensions of health, dimensions of education, and dimensions of living standards. Table 3 shows the results of the MPI calculation, namely there are eight respondents who have a weighting value of more than $33 \%$ so that the score of the MPI is as follows: 
Table 3

Multidimensional Poverty Measures for Marine Capture Fishermen

\begin{tabular}{|c|c|c|c|c|c|c|c|c|c|}
\hline \multirow{4}{*}{ MPI Indicators } & \multicolumn{8}{|c|}{ Eight poor respondents according to MPI category } & \multirow{3}{*}{$\sum$} \\
\hline & 1 & 2 & 3 & 4 & 5 & 6 & 7 & 8 & \\
\hline & \multicolumn{8}{|c|}{ Household size } & \\
\hline & 5 & 5 & 6 & 5 & 6 & 5 & 4 & 9 & 45 \\
\hline \multicolumn{10}{|l|}{ Health } \\
\hline - Nutrition & 0 & 0 & 0 & $1_{(0.167)}$ & $1_{(0.167)}$ & $1_{(0.167)}$ & 0 & $1_{(0.167)}$ & \\
\hline - Child mortality & $1_{(0.167)}$ & $1_{(0.167)}$ & $1_{(0.167)}$ & 0 & 0 & 0 & $1_{(0.167)}$ & 0 & \\
\hline \multicolumn{10}{|l|}{ Education } \\
\hline - Years of schooling & $1_{(0.111)}$ & $1_{(0.111)}$ & $1_{(0.111)}$ & $1_{(0.111)}$ & $1_{(0.111)}$ & $1_{(0.111)}$ & $1_{(0.111)}$ & $1_{(0.111)}$ & \\
\hline - School attendance & $1_{(0.111)}$ & $1_{(0.111)}$ & 0 & 0 & 0 & 0 & 0 & $1_{(0.111)}$ & \\
\hline \multicolumn{10}{|l|}{ Living Standard } \\
\hline - Cooking fuel & $1_{(0.067)}$ & $1_{(0.067)}$ & 0 & 0 & 0 & 0 & 0 & $1_{(0.067)}$ & \\
\hline - Sanitation & 0 & 0 & $1_{(0.067)}$ & 0 & 0 & $1_{(0.067)}$ & 0 & $1_{(0.067)}$ & \\
\hline - Water & 0 & 0 & $1_{(0.067)}$ & 0 & 0 & 0 & 0 & 0 & \\
\hline - Electricity & 0 & 0 & 0 & 0 & 0 & 0 & 0 & 0 & \\
\hline - Floor & 0 & 0 & 0 & $1_{(0.067)}$ & $1_{(0.067)}$ & $1_{(0.067)}$ & $1_{(0.067)}$ & $1_{(0.067)}$ & \\
\hline - Assets & 0 & 0 & 0 & 0 & 0 & 0 & 0 & 0 & \\
\hline Sensor score $(>0.333)$ & 0.456 & 0.456 & 0.412 & 0.345 & 0.345 & 0.412 & 0.345 & 0.590 & \\
\hline Intensity of poverty (A) & 2.280 & 2.280 & 2.472 & 1.725 & 2.070 & 2.060 & 1.380 & 5.310 & 19.577 \\
\hline
\end{tabular}

Source: Primary data, 2018

Weight for indicators of health: 0.167

Weight for indicators of education: 0.111

Weight for indicators of living standard: 0.067

Intensity of poverty (A) per respondents: sensor score $\mathrm{x}$ household size

Multidimensional Headcount Ratio $(H)=\frac{\sum \text { household size of poor respondents }}{\sum \text { household size of total rspondents }}=\frac{45}{388}=0.116$

Intensity of Poverty $(A)=\frac{19.577}{45}=0.435$

So : $M P I=H \times A=0.116 \times 0.435=0.05$

The results of MPI calculation showed that the level of poverty of marine capture fishermen in Bengkulu Province is 0.05 or $5 \%$ and based on poverty indicators according to MPI (Fig. 6), most fishermen have very low levels of education. The link between poverty and education is very large because education provides the ability to develop through the mastery of knowledge and skills. Education also instils awareness of the importance of human dignity. Educating and providing knowledge means reaching the future. This should be the spirit to continue to make efforts to educate the nation (Suryawati, 2005). Siregar \& Wahyuniarti (2008) in their research found that education, as measured by the number of people who graduated from junior high, high school, and diploma had a significant and significant effect on the decline in the number of poor people. 


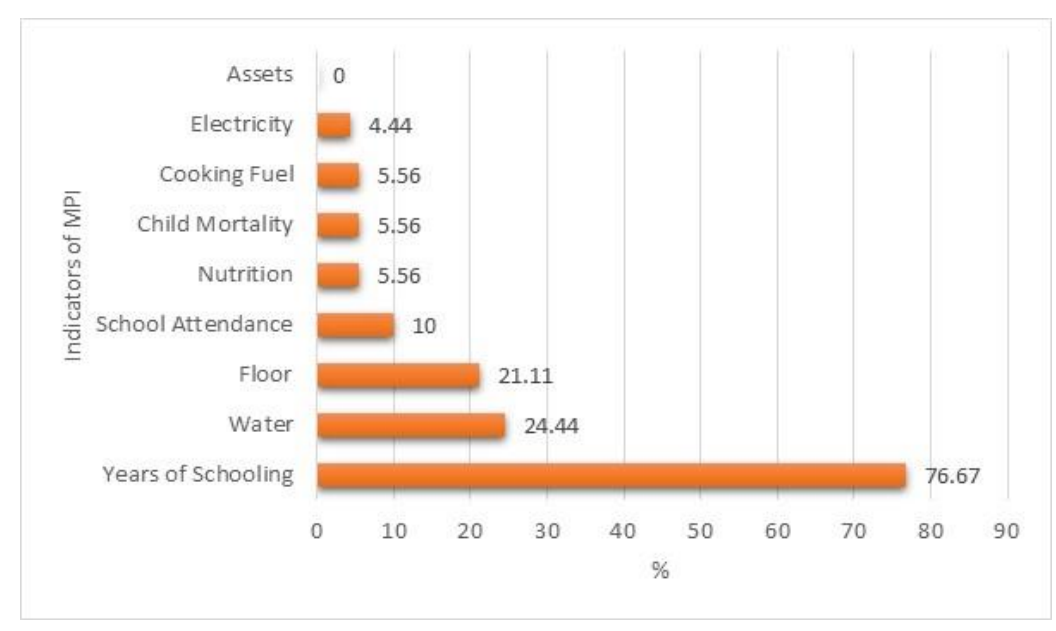

Figure 6. The calculation of Poverty according to MPI

This reflects that the development of human capital through education is an important determinant for reducing the number of poor people. The results of Nasir \& Maulizar (2008) research also state that the relationship between the education level of the head of household and household poverty is positive. A household with a low education level of the head of the household, the tendency to become poor will be greater than the high level of education.

\subsection{Poverty Model of Marine Capture Fishermen}

Based on estimation results (Table 3), so the regression Single Dimensional Poverty Model is as follows:

$\mathrm{Y}=1.306-0.067 \mathrm{X}_{1}+0.044 \mathrm{X}_{2}-0.047 \mathrm{X}_{3}-0.277 \mathrm{X}_{4}-0.016 \mathrm{X}_{5}+0.050 \mathrm{X}_{6}-0.194 \mathrm{X}_{7}-1.238 \mathrm{X}_{8}+$ $0.115 \mathrm{X}_{9}+0.000 \mathrm{X}_{10}+\varepsilon_{\mathrm{i}}$

and Multidimensional Poverty Model is as follows:

$$
\begin{aligned}
& Y=-9.858+0.134 X_{1}+0.024 X_{2}+0.035 X_{3}+1.093 X_{4}-0.019 X_{5}+0.002 X_{6}+0.017 X_{7}+0.863 X_{8} \\
& +0.124 X_{9}+0.000 X_{10}+\varepsilon_{i}
\end{aligned}
$$

The single and multidimensional poverty models have Nagelkerke $\mathrm{R}^{2}$ values that are not much different, namely 0.320 and 0.331 . This means that if a partial analysis is done, together independent variables can only explain the dependent variable at $32.0 \%$ and $33.1 \%$, and the rest can be explained by other variables not included in this poverty model. Other variables such as the number of $A B K$, the number of fishing gear used, the use of capture technology, and the number of fishing days may be considered to explain the poverty level of fishermen. The significance value of the two models shows a value greater than 0.05 , which means that the independent variables used in the model, together influence the poverty level of fishermen in the coastal areas of Bengkulu. The results of the Hosmer and Lemeshow Test of both models also show a significance value greater than $0.05(0.618>0.05$ and $0.076>0.05)$, which means that both models have sufficiently explained the poverty level of fishermen in Bengkulu 
(showing the goodness of fit). Factors that influence the poverty of fishermen based on Table 4 are ship weight, fishing distance, and household size.

\subsubsection{Ship weight}

The poverty level of fishermen in the single dimensional model is influenced by ship weight, which means that the increase in vessel weight will increase the poverty of fishermen in Bengkulu province. Measuring poverty with single dimensions is done by approaching income and increasing ship weight will increase ship fuel costs thereby reducing the income earned by fishermen. The increase in ship weight for traditional fishermen will increase fishing cost, because the quantity of fuel needed will be more and the price of fuel will continue to increase. The addition of the ship weight will also require additional crew, supplies and logistics needed to go to sea. This means that there are additional costs of fishing, while fishermen do not have certainty in earning income. Sometimes fishermen spend more on fishing cost than the income they receive.

Marine capture fishermen in Bengkulu are traditional fishermen who use fishery resources with traditional fishing equipment, small business capital, and relatively simple fishing organizations. In everyday life, traditional fishermen are more oriented to fulfilling their daily needs, in the sense that the results of the allocation of catches that are sold are used more to meet basic daily needs, especially food, and not to be reinvested for the development of business scale. Technically, fishermen's income depends on the selling value of fish caught and fishing cost. The selling value of fish caught is determined by the availability of fish stocks in the sea, the efficiency of fishing technology, the selling price of fish, and the season of fishing. Uncertainty of fishermen in going to sea causes the income received by fishermen is uncertain, especially when the famine occurs, fishermen cannot have income (Kusnadi, 2002).

Table 4

Result Estimation

\begin{tabular}{|c|c|c|c|c|c|c|}
\hline \multirow[t]{2}{*}{ Variables } & \multicolumn{3}{|c|}{ Single Dimensional Poverty } & \multicolumn{3}{|c|}{ Multidimensional Poverty } \\
\hline & $\mathrm{B}$ & S.E & Sig & $\mathrm{B}$ & S.E & Sig \\
\hline (costant) & 1.306 & 1.786 & 0.465 & -9.858 & 4.097 & 0.016 \\
\hline Years of schooling (X1) & -0.067 & 0.082 & 0.415 & 0.134 & 0.170 & 0.430 \\
\hline Age (X2) & 0.044 & 0.039 & 0.254 & 0.024 & 0.056 & 0.661 \\
\hline Experience (X3) & -0.047 & 0.047 & 0.321 & 0.035 & 0.068 & 0.608 \\
\hline Household member (X4) & -0.277 & 0.257 & 0.283 & 1.093 & 0.458 & $0.017 *$ \\
\hline Catch capacity (X5) & -0.016 & 0.012 & 0.188 & -0.019 & 0.025 & 0.440 \\
\hline Ship weight (X6) & 0.050 & 0.026 & $0.049 *$ & 0.002 & 0.045 & 0.961 \\
\hline Worktime $(\mathrm{X} 7)$ & -0.194 & 0.145 & 0.183 & 0.017 & 0.205 & 0.935 \\
\hline Ship ownership (X8) & -1.238 & 0.903 & 0.170 & 0.863 & 1.507 & 0.567 \\
\hline Distance (X9) & 0.115 & 0.058 & $0.049 *$ & 0.124 & 0.098 & 0.204 \\
\hline Asset Value (X10) & .000 & 0.000 & 0.300 & 0.000 & 0.000 & 0.837 \\
\hline Variables in the Equation & \multicolumn{3}{|c|}{$\begin{array}{l}* \text { significant } \alpha=5 \% \\
\text { Respondent }=90 \\
\text { Cox \& Snell R Square }=0.231 \\
\text { Nagelkerke R Square }=0.320 \\
\text { Sig. } 0.002<0.05 \\
\text { Sig. Hosmer and Lemeshow Test }= \\
0.618>0.05 \text { (Goodness of fit) }\end{array}$} & \multicolumn{3}{|c|}{$\begin{array}{l}*_{\text {significant }} \alpha=5 \% \\
\text { Respondent }=90 \\
\text { Cox \& Snell R Square }=0.149 \\
\text { Nagelkerke R Square }=0.331 \\
\text { Sig. } 0.000<0.05 \\
\text { Sig. Hosmer and Lemeshow Test }= \\
0.076>0.05 \text { (Goodness of fit) }\end{array}$} \\
\hline
\end{tabular}

Source: Primary Data, 2018 


\subsubsection{Fishing distance}

The distance of fishing affects the level of poverty of fishermen in the coastal areas of Bengkulu. The distance regression coefficient is 0.115 , which means that if the distance increases by one mile, the poverty level of fishermen will increase by 0.115 . Increasing the distance will allow fishermen to add to the catch, but it will also increase the cost of fishing issued by fishermen. The far distance of fishing means that fishermen must prepare more ship fuel and fishing time will also be longer. Addition of fuel and fishing time will cause additional fishing costs, while the income earned by fishermen is uncertain. Simple fishing technology makes fishermen inefficient in catching fish, so it is less likely for fishermen to add catches if the distance to the sea is farther away.

\subsubsection{Household size}

The poverty level with multidimensional measurements is influenced by household size, which means that the addition of family members will increase fisherman poverty. Multidimensional measurement of poverty involves the number of family members, because the inability of the head of the family to meet his family's needs will affect the poverty level of the family as a whole.The number of families is an important factor affecting household poverty (Chemichovsky \& Meesook, 1981; Alamgir \& Achmed, 1988; Kuznet, 2002; Gaiha, 1987; Firdausy \& Tisdell, 1992). This factor may affect poverty in two directions. First, it may directly affect poverty, as long as household incomes remain the same, increasing numbers of families will reduce the level of real consumption of family members. The number of dependents in the household (both children, productive age members who do not work and the elderly) is likely to reduce welfare in the household and eventually occur in household poverty (Lanjouw and Ravallion, 1995). Second, even if each household member has income, per capita income can decrease with increasing numbers of families regarding diminishing marginal productivity (Kuznet, 2002; Firdausy \& Tisdell, 1992).

\section{CONCLUSION}

The problem of poverty cannot only be defined from a one-dimensional perspective. Currently, poverty is more often associated with the economic dimension since it is most easily observed, measured, and compared. Furthermore, poverty is also related to various dimensions including social, cultural, sociopolitical, environmental (natural and geographical) dimensions, health, education, religion, and manners. Measuring poverty with a single dimensional aspect has limitations because it only looks at the income side. While the measurement of poverty with multidimensional method involves various aspects except for the income. Poverty criteria according to FAO have the highest percentage of fishermen for the single-dimensional group, which is $33.33 \%$. While the multidimensional poverty group which has the highest percentage of fishermen's poverty is based on the criteria set by BPS, which is $30 \%$. Based on these results, it is important to combine between one-dimensional and multidimensional poverty measurement. The results of poverty measurement will be more comprehensive and accurate so that various poverty alleviation policies have more real opportunities to succeed and be precisely targeted at the poor groups in Indonesia. The shipping weight, distance and household members affect the poverty of marine capture fishermen in Bengkulu coastal area. 


\section{ACKNOWLEDGEMENT}

This article was written as a part of dissertation research entitled "Poverty and Vulnerability of Marine Capture Fishermen to Climate Change and Its Adaptation Strategies in the Coastal Regions of Java and Sumatra". The authors also gratefully acknowledge the financial support of the Ministry of Research, Technology and Higher Education (Kemristekdikti) together with the Education Fund Management Institute (LPDP) Indonesia. The views expressed in this paper are those of the authors and should not be attributed to the Indonesian Government.

\section{REFERENCES}

Acheson, J. M. (1981). Anthropology of fishing. Annual review of anthropology, 10(1), 275-316.

Agola, N. O., \& Awange, J. L. (2014). Globalized poverty and environment. 21 ${ }^{\text {st }}$ Century Challenges and Innovative Solutions. Springer, Berlin Heidelberg. doi: 10.1007/978-3-642-39733-2.

Alamgir, M., \& Ahmed, S. (1988). Poverty and income distribution in Bangladesh. Rural poverty in South Asia, 11-38.

Alkire, S., \& Foster, J. (2011). Understandings and misunderstandings of multidimensional poverty measurement. The Journal of Economic Inequality, 9(2), 289-314.

Alkire, S., \& Santos, M. E. (2010). Acute multidimensional poverty: A new index for developing countries. SSRN Electronic Journal. doi: http://dx.doi.org/10.2139/ssrn.1815243.

Boedhisantoso, S. (1999). Komunitas lokal di kawasan pesisir dan pemberdayaannya. Makalab Lokakarya Pembangunan Pranata Sosial Komunitas Pesisir. Depok.

BPS (Central Bureau of Statistics). (2017). Bengkulu Province in Figures.

Chernichovsky, D., \& Meesook, O. A. (1981). Poverty in Indonesia: A profile. World Bank Staff Working Paper, 671, Washington DC.

Emmerson, D. K. (1980). Rethinking artisanal fisheries development: Western concepts, Asian experiences. World Bank Staff Working Paper No. 423.

Faturochman, F., \& Molo, M. (1994). Karakteristik rumah tangga miskin di Daerah Istimewa Yogyakarta. Jurnal Populasi 5(1).

Firdausy, C., \& Tisdell, C. A. (1992). Determinants of rural income and poverty at the village level in Bali, Indonesia. Malaysian Journal of Economic Studies, 29(1), 19-34.

Gaiha, R. (1987). Inequality, earning and participation among the poor in rural India. The Journal of Development Studies, 23(4), 491-508

Harahap, S. S. (2006). Analisis kritis atas laporan keuangan. Jakarta: PT. Raja Grafindo Persada.

Hermanto, S., (1995). Kemiskinan di pedesaan: Masalah dan alternatif penanggulangannya. Pusat Penelitian Sosial Ekonomi Pertanian. Badan Penelitian dan Pengembangan Pertanian. Bogor: IPB

Kuncoro, M., (2006). Ekonomika Pembangunan: Teori, Masalab, dan Kebijakan. Yogyakarta: UPP STIM YKPN.

Kusnadi. (2002). Konflik Sosial Nelayan Kemiskinan dan Perebutan Sumberdaya Perikanan. Yogyakarta: LKiS Pelangi Aksara.

Kuznet, S., (2002). Economic development, the family, and income distribution. Selected essays. Cambridge University Press

Lanjouw, P., \& Ravallion, M. (1995). Poverty and household size. The Economic Journal, 105(433),1415-1434.

Narayan, D., \& Petesch, P. (2007). Agency, opportunity structures, and poverty escapes. Moving out of poverty: Crossdisciplinary perspectives on mobility, 1(1). Palgrave Macmillan for the World Bank. Basingstoke.

Nasir, M., \& Maulizar, S. D. (2008). Analisis faktor-faktor yang mempengaruhi kemiskinan rumah tangga di Kabupaten Purworejo. Jurnal Eksekutif, 5(4).

Panayotou, T. (1982). Management concepts for small-scale fisheries, economic, and social aspect. FAO fisheries technical paper, 228. Rome. Italy. 
Prayitno, H., \& Aryad, L. (1987). Petani dan kemiskinan. Yogyakarta: BPFE.

Rahimi, F. A. F. (2015). The impact of security and regional integration on poverty reduction in Afghanistan. Journal of International Studies, 8(1), 183-195. https://doi.org/10.14254/2071-8330.2015/8-1/16

Siregar, H., \& Wahyuniarti, D. (2008). Dampak pertumbuhan ekonomi terhadap penurunan jumlah penduduk miskin. Retrieved from http://pse.litbang.deptan.go.id/ind/pdffiles/PROS 2008 MAK3.pdf

Setiadi. (2006). Mengungkap pengentasan kemiskinan secara partisipatoris. Retrieved from http:/ / www.ugm.ac.id/index.php?page= rilis\&artikel $=307$

Subade, R.F., \& Abdullah, N.M.R. (1993). Are fishers profit maximizers? The case of gillnetters in Negros Occidental and Iloilo, Philippines. Asian Fisheries Science, 6, 39-49.

Suryawati, C. (2005). Memahami kemiskinan secara multidimensional. Jurnal Manajemen Pelayanan Kesehatan, 8(3), 121129.

Viet-Wilson, J. H. (1986). Paradigm of poverty: A rehabilitation of BS Rowntree. Journal of Social Policy, 15(1), 69-99. 